\begin{tabular}{|l|l|l||}
\hline \multicolumn{2}{|c|}{ PublisherInfo } \\
\hline \hline PublisherName & $:$ & BioMed Central \\
\hline \hline PublisherLocation & $:$ & London \\
\hline \hline PublisherImprintName & $:$ & BioMed Central \\
\hline \hline
\end{tabular}

\title{
Eaten by Daddy
}

\begin{tabular}{|l|l|l||}
\hline \multicolumn{2}{|c|}{ ArticleInfo } \\
\hline \hline ArticleID & $:$ & 4065 \\
\hline \hline ArticleDOI & $:$ & $10.1186 /$ gb-spotlight-20010426-02 \\
\hline \hline ArticleCitationID & $:$ & spotlight-20010426-02 \\
\hline \hline ArticleSequenceNumber & $:$ & 136 \\
\hline \hline ArticleCategory & $:$ & Research news \\
\hline ArticleFirstPage & $:$ & 1 \\
\hline \hline ArticleLastPage & $:$ & 2 \\
\hline \hline & & RegistrationDate : 2001-04-26 \\
ArticleHistory & $:$ & OnlineDate \\
\hline \hline ArticleCopyright & $:$ & BioMed Central Ltd2001 \\
\hline \hline ArticleGrants & $:$ & \\
\hline \hline ArticleContext & $:$ & 130592211 \\
\hline \hline
\end{tabular}




\section{Jonathan B Weitzman}

Email: jonathanweitzman@hotmail.com

There is no genetic evidence for filial cannibalism, in which parents eat their own offspring. In the April 24 Proceedings of the National Academy of Sciences, DeWoody et al. document filial cannibalism in fish in nature (Proc Natl Acad Sci USA 2001, 98:591-596). The authors captured male fish, of the tessellated darter and two sunfish species, and examined the cannibalized contents of the stomachs of nest-guarding males by polymorphic microsatellite marker analysis. They found that 10 out of 11

cannabilistic males contained offspring that they had sired. The authors suggest that a father fish may eat his own young to gain a source of food energy, thereby avoiding the need to leave the nest to forage, which would expose his progeny to predation risks.

\section{References}

1. The evolution of filial cannibalism and female mate choice strategies as resolutions to sexual conflict in fishes.

2. Proceedings of the National Academy of Sciences, [http://www.pnas.org] 